\title{
Faktor-Faktor Yang Berhubungan Dengan Hygiene Sanitasi Indutri Pengerajin Kue
}

\section{Factors Related To The SAanitation Of The Cake Craftsman Industry}

\author{
Julia Ulfa $\mathrm{M}^{1}$, H. Subakir ${ }^{2}$, Sugiarto ${ }^{3}$ \\ ${ }^{123}$ Sekolah Tinggi Ilmu Kesehatan Harapan Ibu Jambi. Program Studi Keehatan Masyarakat \\ ${ }^{1,3}$ Pogram Studi Kesehatan Masyarakat \\ *Koresponding Penulis: Julia Ulfa $\mathrm{M}^{1}, \mathrm{H}$. Subakir ${ }^{2}$, Sugiarto ${ }^{3}$
}

\begin{abstract}
Abstrak
Badan POM tahun 2017 di Indonesia telah mencatat 57 penderita keracunan makanan. Dilaporkan jumlah orang yang terpapar sebanyak 5293 orang, kasus KLB keracunan pangan yang dilaporkan sebanyak 2041 orang sakit dan 3 orang meninggal dunia. Puskesmas Putri Ayu Kota Jambi memiliki $14(46,7 \%)$ industri pengrajin kue yang tidak memenuhi syarat. Tujuan penelitian ini untuk mengetahui faktor-faktor yang berhubungan dengan hygiene sanitasi industri pengrajin kue di Wilayah Kerja Puskesmas Putri Ayu Kota Jambi. Penelitian ini merupakan penelitian kuantitatif dengan pendekatan Cross Sectional. Pengumpulan data dilakukan dengan observasi dan wawancara kemudian dianalisis secara Univariat dan Bivariat. Instrumen yang digunakan kuesioner dan form inspeksi kesehatan lingkungan. Total populasi penelitian ini adalah seluruh pemilik industri kue di Wilayah Kerja Puskesmas Putri Ayu Kota Jambi sebanyak 30 industri kue. Penelitian ini dilakukan tanggal 1423 Agustus. Dari 30 responden, sebanyak 60\% memiliki pengetahuan buruk, 53,3\% memiliki sikap negatif, 63,3\% memiliki motivasi rendah dan 53,3\% menyatakan peran petugas kurang baik. Hasil penelitian menunjukan terdapat hubungan antara pengetahuan ( $p$-value $=0,030)$ sikap $(p$-value $=0,030)$ motivasi ( $\mathrm{p}$-value $=0,046)$ dan peran petugas $(\mathrm{p}$-value $=0,003)$ dengan hygiene sanitasi industri pengrajin kue.
\end{abstract}

Kata Kunci : Hygiene sanitasi, Industri pengrajin kue

\begin{abstract}
National Agency of Drug and Food Control (BPOM) of Indonesian has recorded 57 patients with food poisoning in 2017. Reported number of people exposed to as many as 5293 people, outbreaks offood poisoning cases resported as many as 2041 people were sick and 3 people died. Putri Ayu health center in the city of Jambi has 40 (46,7\%) cookie crafs industries that do not qualify for health. The purpose of this study was to determine the factors associated with the sanitation of the cake craf industry sanitation in the working area of Putri Ayu Health Center in Jambi City. This research is a quantitative study with cross sectional design. Data collected by observation and interviews and then analyzed by univariate and bivariate. The instrument used was a questionnaire and an environmental health inspection form. Total population of this study were all cake industry owners in the working area of Putri Ayu Health Center in Jambi as many as 30 cake industries. This assessment was carried out on 14-23 August 2019. From 30 respondent 60\% had bad knowledge, 53,3\% had negative attitudes, 63,3\% had low motivation and 54,3\% stated the role of officers was not good. The results showed there was a relationship between knowledge ( $p$ value $=0,030)$ attitude $(p$ value $=0,030)$ motivation ( $p$ value $=$ 0,046 ) and the role of officers ( $p$ value $=0,003$ ) with sanitation of the cake craft industry sanitation. It is hoped that health workes will educate the baking industry so that the owners have broader insight on the importance of sanitation hygiene
\end{abstract}

Keywords: Sanitation Hygiene, Cake Craft Industry 


\section{PENDAHULUAN}

Undang-Undang Nomor 36 Tahun 2009 tentang Kesehatan dalam Pasal 111 ayat (1) menyatakan bahwa makanan dan minuman yang digunakan masyarakat harus didasarkan pada standar dan/atau persyaratan kesehatan. Terkait hal tersebut di atas, Undang-Undang tersebut mengamanahkan bahwa makanan dan minuman yang tidak memenuhi ketentuan standar, persyaratan kesehatan, dan/atau membahayakan kesehatan dilarang untuk diedarkan, ditarik dari peredaran, dicabut izin edar dan disita untuk dimusnahkan sesuai dengan ketentuan peraturan perundang-undangan (BPOM, 2012).

Badan POM juga telah mencatat 57 berita keracunan pangan yang diperoleh dari media massa dan PHEOC (Public Health Emergency Operating Center). Dilaporkan jumlah orang yang terpapar sebanyak 5293 orang, sedangkan kasus KLB keracunan pangan yang dilaporkan sebanyak 2041 orang sakit dan 3 orang meninggal dunia (BPOM, 2018).

Makanan yang bersih ialah makanan yang tidak terkontaminasi oleh kotoran dan tidak menampakkan tanda pembusukan oleh bakteri. Dari jasad renik hingga zat kimia berbahaya, penyebab penyakit dapat ditularkan pada manusia melalui banyak jalan, yaitu : udara, air, tanah, kontak langsung antar orang, dan makanan. Sebagian penyakit dapat ditularkan lewat makanan oleh binatang atau alat masak. Banyak sekali cara penyebaran zat pencemar (dan kontaminasi silang) (Arisman, 2012).

Industri Rumah Tangga Pangan (IRTP) adalah perusahaan pangan yang memiliki tempat usaha di tempat tinggal dengan peralatan pengolahan pangan manual hingga semi otomatis.PIRT terdiri dari industry pengrajin kue, industry pengrajin pempek, manisan buah, peyek, bumbu masak, dodol dan dll (BPOM, 2012).

Berdasarkan data dari Kemenkes RI, presentasi Tempat Pengolahan Makanan yang memenuhi syarat hanya mencapai $18,04 \%$ dan belum memenuhi target Rencana Strategis Kementrian Kesehatan tahun 2017 untuk tempat pengolahan makanan memenuhi syarat kesehatan yaitu sebesar 20\%. Pada tahun 2018 tempat pengolahan makanan di Indonesia baru mencapai 24,8\% sehingga belum mencapai taerget nasional yaitu 26\% (Kemenkes RI, 2018).

Dari 20 Puskesmas yang ada di Kota Jambi, jumlah Industri Pengrajin Makanan yang berada di Puskesmas Putri Ayu berjumlah 72 industri pengrajin makanan dan yang di periksa hanya 29 industri pengrajin makanan dan jumlah yang memenuhi syarat yaitu sebanyak $51,72 \%$ industri pengrajin makanan ( Dinas Kesehatan Kota Jambi, 2018).

Dari hasil penelitian Fajriansyah (2017) hasil penelitian diketahui pengelolaan pembuatan kue rumahan masih banyak yang kurang baik yaitu sebesar 60,0\%.walaupun 
umumnya pengetahuan tinggi $(65,7 \%)$, tetapi mempunyai hygienitas yang kurang baik sebesar $60,0 \%$.begitu juga dengan kebiasaan dalam pengelolaan pembuatan kue umumnya kurang bak $(71,5 \%)$ (Fajriansyah, 2016).

faktor-faktor yang mempengaruhi perilaku terbagi menjadi 3 tahapan yaitu faktor predisposisi, faktor pendukung dan faktor penguat. Bila pengelola dan penjamah makanan memiliki pengetahuan yang cukup atau memadai tentang persyaratan makanan maka kondisi hygiene dan sanitasi makanan akan terpelihara sesuai dengan indicator yang berlaku (Notoatmodjo, 2007).

Berdasarkan uraian diatas, diketahui bahwa higiene sanitasi industri pengrajin kue yang tidak memenuhi syarat masih tinggi. Jika tidak di lakukan pengelolaan yang tepat oleh pemilik industry pengrajin kue baik dari segi makanan, tempat, dan penjamah makanan maka dapat menimbulkan penyakit atau gangguan kesehatan. Oleh karena itu, peneliti akan melakukan penelitian tentang faktor-faktor yang berhubungan dengan higiene sanitasi industri pengrajin kue di wilayah kerja Puskesmas Putri Ayu Kota Jambi Tahun 2019.

\section{METODE PENELITIAN}

Penelitian ini adalah penelitian kuntitatif dengan pendekatan cross sectional yang bertujuan untuk mengetahui faktor-faktor yang berhubungan dengan higiene sanitasi industri pengrajin kue diwilayah kerja Puskesmas Putri Ayu Kota Jambi. Penelitian ini dilakukan dengan cara observasi menggunakan form inspeksi dari E Monef HSP dan wawancara menggunakan kuesioner untuk mengukur variabel pengetahuan, sikap, motivasi dan peran petugas. Populasi penelitian ini adalah seluruh industri pengrajin kue yang ada di wilayah kerja Puskesmas Putri Ayu Kota Jambi. Teknik pengambilan sampel menggunakan teknik total sampling dengan jumlah sampel sebanyak 30 responden. Data dianalisis secara univariat dan bivariat kemudian dianalisis menggunakan Uji Chi-Square.

\section{HASIL DAN PEMBAHASAN}

Penelitian ini dilakukan pada seluruh industri pengrajin kue di Wilayah Kerja Puskesmas Putri Ayu Kota Jambi sebanyak 30 industri pengrajin kue dan didapatkan hasil penelitiannya sebagai berikut. 
Tabel 1. Faktor-Faktor yang Berhubungan dengan Hygiene Sanitasi Industri Pengrajin Kue di Wilayah Kerja Puskesmas Putri Ayu Kota Jambi

\begin{tabular}{|c|c|c|c|c|c|c|c|c|}
\hline \multirow[t]{3}{*}{ No } & \multirow[t]{3}{*}{ PENGETAHUAN } & \multicolumn{4}{|c|}{ Hygiene Sanitasi } & \multirow{2}{*}{\multicolumn{2}{|c|}{ Total }} & \multirow[t]{3}{*}{ p-value } \\
\hline & & \multicolumn{2}{|c|}{ Baik } & \multicolumn{2}{|c|}{ Tidak Baik } & & & \\
\hline & & $\mathbf{n}$ & $\%$ & $\mathbf{n}$ & $\%$ & $\mathbf{n}$ & $\%$ & \\
\hline 1 & Rendah & 3 & 25,0 & 9 & 75,0 & 12 & 100 & 0,030 \\
\hline 2 & Tinggi & 13 & 72,2 & 5 & 27,8 & 18 & 100 & \\
\hline & Total & 16 & 53,3 & 14 & 46,7 & 30 & 100 & \\
\hline
\end{tabular}

Hasil analisis menunjukan bahwa dari 12 responden yang memiliki pengetahuan rendah, terdapat $9(75,0 \%)$ memiliki hygiene sanitasi yang tidak baik dan $3(25,0 \%)$ memiliki hygiene sanitasi yang baik. Sedangkan dari 18 responden berpengetahuan tinggi terdapat $5(27,8 \%)$ yang tidak baik dan $13(72,2 \%)$ memiliki hygiene sanitasi yang baik.

Dari hasil uji statistic diperoleh nilai $\mathrm{p}$-value $=0,030$, artinya nilai $\mathrm{p}$-value $<0,05(\alpha=$ 5\%). Hal ini menunjukkan bahwa ada hubungan yang bermakna antara pengetahuan dengan hygiene sanitasi industri pengrajin kue di wilayah kerja puskesmas Putri Ayu Kota Jambi Tahun 2019.

Tabel 2. Faktor-Faktor yang Berhubungan dengan Hygiene Sanitasi Industri Pengrajin Kue di Wilayah Kerja Puskesmas Putri Ayu Kota Jambi

\begin{tabular}{|c|c|c|c|c|c|c|c|c|}
\hline \multirow[t]{3}{*}{ No } & \multirow[t]{3}{*}{ SIKAP } & \multicolumn{4}{|c|}{ Hygiene Sanitasi } & \multirow{2}{*}{\multicolumn{2}{|c|}{ Total }} & \multirow[t]{3}{*}{ p-value } \\
\hline & & \multicolumn{2}{|c|}{ Baik } & \multicolumn{2}{|c|}{ Tidak Baik } & & & \\
\hline & & $\mathbf{n}$ & $\%$ & $\mathbf{n}$ & $\%$ & $\mathbf{n}$ & $\%$ & \\
\hline 1 & Negatif & 4 & 25,0 & 12 & 75,0 & 16 & 100 & 0,003 \\
\hline 2 & Positif & 12 & 85,7 & 2 & 14,4 & 14 & 100 & \\
\hline & Total & 16 & 53,3 & 14 & 46,7 & 30 & 100 & \\
\hline
\end{tabular}

Hasil analisis dari 16 responden mempunyai sikap negative, terdapat $12(75,0 \%)$ memiliki hygiene sanitasi yang tidak baik dan terdapat $4(25,0 \%)$ yang memiliki hygiene sanitasi yang 
baik. Sedangkan 14 responden yang memiliki sikap positif, terdapat $2(14,4 \%)$ memiliki hygiene sanitasi tidak baik dan terdapat $12(85,7 \%)$ memilki hygiene sanitasi yang baik.

Dari hasil uji statistic diperoleh nilai $\mathrm{p}$-value $=0,003$, artinya nilai p-value $<0,05(\alpha=$ 5\%). Hal ini menunjukkan bahwa ada hubungan yang bermakna antara sikap dengan hygiene sanitasi industri pengrajin kue di wilayah kerja Puskesmas Putri Ayu Kota Jambi Tahun 2019.

Tabel 3. Faktor-Faktor yang Berhubungan dengan Hygiene Sanitasi Industri Pengrajin Kue di Wilayah Kerja Puskesmas Putri Ayu Kota Jambi

\begin{tabular}{|c|c|c|c|c|c|c|c|c|}
\hline \multirow[t]{3}{*}{ No } & \multirow[t]{3}{*}{ MOTIVASI } & \multicolumn{4}{|c|}{ Hygiene Sanitasi } & \multirow{2}{*}{\multicolumn{2}{|c|}{ Total }} & \multirow[t]{3}{*}{ p-value } \\
\hline & & \multicolumn{2}{|c|}{ Baik } & \multicolumn{2}{|c|}{ Tidak Baik } & & & \\
\hline & & $\mathbf{n}$ & $\%$ & $\mathbf{n}$ & $\%$ & $\mathbf{n}$ & $\%$ & \\
\hline 1 & Rendah & 7 & 36,8 & 12 & 63,2 & 19 & 100 & 0,046 \\
\hline 2 & Tinggi & 9 & 81,8 & 2 & 18,2 & 11 & 100 & \\
\hline & Total & 16 & 100 & 14 & 100 & 30 & 100 & \\
\hline
\end{tabular}

Hasil analisis dari 19 responden mempunyai motivasi rendah, terdapat $12(63,2 \%)$ memiliki hygiene sanitasi tidak baik dan $7(36,8 \%)$ yang memiliki hygiene sanitasi baik. Selanjutnya dari 11 responden yang memiliki motivasi tinggi, terdapat $2(18,2 \%)$ yang tidak baik dan $9(81,8 \%)$ yang memiliki hygiene sanitasi yang baik.

Dari hasil uji statistic diperoleh nilai $\mathrm{p}$-value $=0,046$, artinya nilai $\mathrm{p}$-value $<0,05(\alpha=$ 5\%). Hal ini menunjukkan bahwa ada hubungan yang bermakna antara motivasi dengan hygiene sanitasi industri pengrajin kue di wilayah kerja Puskesmas Putri Ayu Kota Jambi Tahun 2019. 
Tabel 3. Faktor-Faktor yang Berhubungan dengan Hygiene Sanitasi Industri Pengrajin Kue di Wilayah Kerja Puskesmas Putri Ayu Kota Jambi

\begin{tabular}{|c|c|c|c|c|c|c|c|c|}
\hline \multirow[t]{3}{*}{ No } & \multirow[t]{3}{*}{ PERAN PETUGAS } & \multicolumn{4}{|c|}{ Hygiene Sanitasi } & \multirow{2}{*}{\multicolumn{2}{|c|}{ Total }} & \multirow[t]{3}{*}{ p-value } \\
\hline & & \multicolumn{2}{|c|}{ Baik } & \multicolumn{2}{|c|}{ Tidak Baik } & & & \\
\hline & & $\mathbf{n}$ & $\%$ & $\mathbf{n}$ & $\%$ & $\mathbf{n}$ & $\%$ & \\
\hline 1 & Tidak Berperan & 4 & 25,0 & 12 & 75,0 & 16 & 100 & 0,003 \\
\hline 2 & Berperan & 12 & 85,7 & 2 & 14,4 & 14 & 100 & \\
\hline & Total & 16 & 53,3 & 14 & 46,7 & 30 & 100 & \\
\hline
\end{tabular}

Hasil analisis menunjukan bahwa dari 16 responden yang memiliki peran petugas tidak berperan, terdapat $12(75,0 \%)$ memiliki hygiene sanitasi yang tidak baik dan $4(25,0 \%)$ memiliki hygiene sanitasi yang baik. Sedangkan dari 14 responden peran petugas yang berperan $2(14,4 \%)$ memiliki hygiene sanitasi tidak baik dan $12(85,7 \%)$ memiliki hygiene sanitasi yang baik.

Dari hasil uji statistic diperoleh nilai $\mathrm{p}$-value $=0,003$, artinya nilai $\mathrm{p}$-value $<0,05(\alpha=$ 5\%). Hal ini menunjukkan bahwa ada hubungan yang bermakna antara peran petugas dengan hygiene sanitasi industri pengrajin kue di wilayah kerja Puskesmas Putri Ayu Kota Jambi Tahun 2019.

\section{PEMBAHASAN}

Hubungan pengetahuan dengan hygiene sanitasi industri pengrajin kue

Hasil analisis menunjukkan nilai $\mathrm{p}$-value yang diperoleh adalah $\mathrm{p}$-value $=0,030$. Hal tersebut berarti terdapat hubungan antara pengetahuan dengan hygiene sanitasi industri pengrajin kue di Wilayah Kerja Puskesmas Putri Ayu Kota Jambi.

Hal ini sesuai dengan penelitian yang dilakukan oleh Roza Mulyani (2014) yang menyatakan responden dengan pengetahuan baik, mempunyai sikap baik dan berperilaku hygiene.Hasil analisa bivariat ada hubungan antara pengetahuan dengan perilaku hygiene (p 
value 0,032 ) dan tidak ada hubungan antara sikap dengan perilaku hygiene pengolah makanan (p value 0,562$)$.

Hal ini sesuai dengan teori Green dalam Notoatmodjo (2007) dimana perilaku dipengaruhi oleh 3 faktor yaitu salah satunya adalah faktor predisposisi yang mencakup pengetahuan, nilai, sikap, pendidikan dan lainya.

Terdapat hubungan antara pengetahuan dengan hygiene sanitasi karena pengetahuan yang dimiliki responden tinggi sehingga berpengarhu terhadap hygiene sanitasi. Hasil dari penelitian menunjukkan bahwa dari 30 responden yang diwawancarai, $14(46,7 \%)$ responden mempunyai pengetahuan rendah atau kurang dalam hal bahwa harus tersedia tempat pembuangan sampah di ruang produksi. Namun menurut responden tempat pembuangan sampah yang baik tidak harus tertutup, karena menurut responden tempat pembuangan sampah yang terbuka lebih efisien jika dibandingkan dengan tempat pembuangan sampah tertutup.8(26,7\%) responden menyatakan bahwa sarana toilet/jamban tidak harus bersih dan tidak terbuka ke ruang produksi, karena menurut responden toilet yang terbuka dan tidak terbuka ke ruangan produksi tidak menjamin bersih atau tidaknya makanan.

Jika pengetahuan responden tidak ditingkatkan maka akibat yang ditimbulkan adalah tidak akan ada perubahan perilaku hygiene sanitasi yang dimiliki responden. Karena perilaku yang diterapkan pemilik industri kue tidak mengikuti prinsip dan kesehatan penjamah makanan. Sehubungan dengan itu maka perlu dilakukan upaya untuk meningkatkan pengetahuan responden dengan melakukan penyuluhan yang di selenggarakan oleh Petugas Puskesmas dan kegiatan ASMAMI (asosiasi makanan dan minuman) bisa dilaksanakan pada hari sabtu dan minggu di aula puskesmas. 


\section{Hubungan Sikap dengan hygiene sanitasi industri pengrajin kue}

Hasil penelitian menunjukkan nilai p-value yang diperoleh adalah $p$-value $=0,003$. Hal tersebut berarti bahwa terdapat hubungan antara sikap dengan hygiene sanitasi industri pengrajin kue di Wilayah Kerja Puskesmas Putri Ayu Kota Jambi.

Tetapi penelitian ini tidak sesuai dengan penelitian Roza Mulyani (2014) dimana hasil penelitian menunjukkan bahwa tidak terdapat hubungan sikap dengan perilaku hygiene (pvalue $=0,562$. Menuurt Roza Mulyani, sikap tidak selalu berhubungan dengan perilaku, karena sikap yang ditemukkan tidak tercemin dalam perilaku responden.

Adanya hubungan anatar sikap dengan hygiene sanitasi karena responden masih memiliki tingkatan sikap sebatas merespon atau memberikan jawaban apabila ditanya namun belum merasa bertanggung jawab atas segala sesuatu yang dipilihnya dengan segala resiko yang merupakan tingkatan sikap yang paling tinggi. Hasil penelitian dari 30 responden, terdapat $22(73,3 \%)$ responden mempunyai sikap yang negatif dalam hal karyawan mencuci tangan dengan bersih sewaktu memulai mengolah makanan dan sesudah menangani bahan mentah. Responden tidak mencuci tangan menggunakan sabun dan air mengalir tetapi mencuci tangan hanya menggunakan air saja. Menurut responden mencuci tangan dengan air biasa saja itu sudah bersih dan tidak mesti menggunakan sabun. Responden menyatakan bahwa pada saat mengolah makanan boleh saja sambil makan dan minum, karena menurut responden dengan sambil makan bisa mencicipi makanan yang sedang diolah dan tidak mesti pada saat mengolah makanan tidak boleh makan atau minum.

Jika sikap responden tidak mencuci tangan menggunakan sabun dan air yang mengalir sewaktu mengolah makanan maka akibat yang ditimbulkan adalah bisa berpotensi untuk menimbulkan kontaminasi pada makanan yang diolah. Sehubungan dengan itu maka perlu dilakukan upaya untuk meningkatkan sikap responden dengan cara petugas puskesmas lebih 
meningkatkan pengawasan terhadap industri pengrajin kue sehingga sikap responden bias menjadi lebih positif.

\section{Hubungan Motivasi dengan hygiene sanitasi industri pengrajin kue}

Hasil penelitian menunjukkan nilai p-value yang diperoleh adalah p-value $=0,046$. Hal tersebut berarti terdapat hubungan antara motivasi dengan hygiene sanitasi industri pengrajin kue di Wilayah Kerja Puskesmas Putri Ayu Kota Jambi.

Hal ini sesuai dengan penelitian yang dilakukan oleh Erris \& Marinawati (2014) yang menyatakan motivasi berpengaruh terhadap hygiene sanitasi makanan. Hasil uji statistik di peroleh nilai $\mathrm{p}$-value $=0,01$ hal ini berarti bahwa ada hubungan yang signifikan antara motivasi dengan hygiene sanitasi makanan.

Menurut Mathis \& Jackson (2006) motivasi merupakan hasrat di dalam seseorang yang dapat menyebabkan orang tersebut melakukan suatu tindakan. Di dalam proses pembentukan dan perubahan perilaku dipengaruhi oleh beberapa faktor yang berasal dari dalam individu itu sendiri salah satunya adalah motivasi.

Motivasi berasal dari kata motif yang berarti dorongan.Dengan demikian motivasi berarti suatu kondisi yang mendorong atau menjadi sebab seseorang melakukan suatu perbuatan/kegiatan, yang berlangsung secara sadar (Wilson, 2012).

Terdapat hubungan antara motivasi dengan hygiene sanitasi karena responden tidak mempunyai niatan yang kuat untuk mengubah kondisi dapur yang sesuai dengan hygine sanitasi dan responden selalu mengharapkan bantuan dari pemerintah. Dari 30 responden, terdapat $28(93,3 \%)$ responden mempunyai motivasi rendah atau kurang dalam hal tempat penyimpanan bahan makanan pada tempat bersih. Responden tidak memiliki mengupayakan menyimpan bahan pengemas di tempat yang bersih dan tidak tidak diruangan khusus. Menurut responden bahan pengemas bias simpan dimana saja dan tidak harus memiliki tempat penyimpanan yang khusus. 
Jika motivasi yang dimiliki oleh responden tetap rendah dalam hal responden tidak mengupayakan mneyimpan bahan pengemas ditempat yang bersih dan khusus, maka dapat mengakibatkan tidak terjadinya peningkatan hygiene sanitasi dan responden tidak memiliki dorongan untuk melakukan perubahan hygiene sanitasi nya. Sehubungan dengan itu maka perlu dilakukan upaya untuk meningkatkan motivasi responden dengan memberikan penghargaan sertifikat laik hygiene yang diberikan dari Dinas Kesehatan Kota Jambi atau petugas puskesmas dengan tingkat mutu hygiene sanitasi kepada pengrajin kue yang memiliki industri yang bersih dan memenuhi syarat. Dengan memberikan penghargaan dari puskesmas diharapkan industri yang tidak mendapat penghargaan menjadi termotivasi untuk memperhatikan kondisi hygiene sanitasi industri nya.

\section{Hubungan Peran Petugas dengan hygiene sanitasi industri pengrajin kue}

Hasil penelitian menunjukkan nilai $\mathrm{p}$-value diperoleh $\mathrm{p}$-value $=0,003$. Hal tersebut berarti terdapat hubungan antar peran petugas dengan hygiene sanitasi industri pengrajin kue di Wilayah Kerja Puskesmas Putri Ayu Kota Jambi.

Demikian juga, penelitian Harnani \& Utami (2018) menunjukkan hasil bahwa terdapat hubungan antara penyuluhan tenaga kesehatan terhadap hygiene sanitasi rumah makan.Hasil uji statistik diperoleh nilai p-value 0,014 hal ini berarti bahwa ada hubungan yang signifikan antara peran petugas dengan hygiene sanitasi makanan.

Tetapi penelitian ini tidak sesuai dengan penelitian Siti Muslimah (2019) menyatakan tidak terdapat hubungan peran petugas dengan hygiene sanitasi jasaboga golongan A1 dan A2 (p-value $=0,189)$. Tidak ada hubungan peran petugas terhadap hygiene sanitasi jasaboga disebabkan oleh belum terpenuhinya peran petugas sebagai konseling yaitu sebagai tempat bertanya oleh individu untuk memecahkan masalah yang dihadapi masyarakat dalam hal ini bertanya tentang penerapan hygiene sanitasi jasaboga. 
Ada hubungan antara peran petugas kesehatan dengan hygiene sanitasi makanan karena industri pengrajin kue tersebut dari 30 responden, $23(76,7 \%)$ petugas kesehatan tidak berperan dalam hal kunjungan petugas kesehatan 6 bulan terakhir. Pada saat wawancara kepada responden, responden mengatakan tidak pernah di datangi oleh petugas kesehatan kurang dari 6 bulan atau 1 tahun terakhir untuk mengecek atau melakukan penyuluhan. Menurut responden, petugas kesehatan pernah datang untuk mengecek dapur mereka tetapi dalam waktu yang kurang dari 2 tahun terakhir, dan petugas kesehatan juga datang pada saat beberapa bulan industri mereka berjalan. Petugas kesehatan di Puskesmas Putri Ayu menyatakan kurangnya tenaga kesehatan dibidang kesehatan lingkungan serta adanya indikator kesehatan lain yang lebih diutamakan untuk diselesaikan programnya sehingga petugas jarang mengunjungi industri pengrajin kue.

Jika petugas kesehatan tidak melakukan kunjungan secara rutin ke industri pengrajin kue, maka akibat yang ditimbulkan adalah pemilik tidak memiliki wawasan tentang hygiene sanitasi maka tidak ada evaluasi dari petugas kesehatan sehingga pemilik tidak memiliki wawasan yang luas. Maka dari itu perlu dilakukan upaya untuk meningkatkan peran petugas dengan cara petugas Dinas Kesehatan Kota Jambi menegur dan memberikan hukuman petugas puskesmas yang tidak melakukan kunjungan rutin terhadap industri pengrajin makanan terutama industri pengrajin kue.

\section{Kesimpulan}

Hygiene Sanitasi yang memenuhi syarat terdapat $16(53,3 \%)$ dan tidak memenuhi syarat terdapat $14(46.7 \%)$. Ada hubungan antara pengetahuan dengan hygiene sanitasi industri pengrajin kue di wilayah kerja Puskesmas Putri Ayu Kota Jambi Tahun 2019 ( $p$ value 0,030). Ada hubungan antara sikap dengan hygiene sanitasi industri pengrajin kue di wilayah kerja Puskesmas Putri Ayu Kota Jambi Tahun 2019 (p-value 0,03). Ada hubungan antara Motivasi dengan hygiene sanitasi industri pengrajin kue di wilayah kerja Puskesmas Putri Ayu Kota Jambi Tahun 2019 ( $p$-value 0,046). Ada hubungan antara peran petugas 
dengan hygiene sanitasi industri pengrajin kue di wilayah kerja Puskesmas Putri Ayu Kota Jambi Tahun 2019 (p-value 0,003).

\section{SARAN}

Bagi Dinas Kesehatan Kota sebaiknya lebih meningkatkan pemeriksaan kesehatan bagi penjamah makanan salah satunya dengan mengikuti kegiatan kelompok komunitas asmami (asosiasi makanan dan minuman) di kota jambi dan mengadakan penyuluhan terhadap penjamah makanan agar meningkatkan pengetahuan dan sikap. Bagi Puskesmas Putri Ayu sebaiknya memberikan penghargaan berupa sertifikat laik hygiene terhadap industri kue yang memenuhi syarat sehingga pemilik industri kue yang tidak memenuhi syarat termotivasi untuk mendapatkan penghargaan juga.

Petugas kesehatan juga mengadakan pelatihan kepada industri pengrajin kue sehingga pemilik memiliki keterampilan tambahan. Dan petugas puskesmas yang tidak melakukan kunjungan rutin ditegur dan diberi hukuman oleh Dinas Kesehatan Kota. Bagi tempat penelitian yang tidak memenuhi syarat sebaiknya lebih meningkatkan hygiene sanitasi dan industri yang memenuhi syarat tetap mempertahankan kondisi hygiene sanitasi. Bagi Penelitian Lain bisa melakukan penelitian dengan variable lain selain teori Lawrence Green.

\section{DAFTAR PUSTAKA}

Badan Pengawas Obat dan Makanan. (2012). Pedoman Pemberian Sertifikat Produksi Pangan Industri Rumah Tangga. Jakarta: BPOM.

Badan Pengawasan Obat dan Makanan. (2018). Laporan Tahunan BPOM Tahun 2017. Jakarta : BPOM

Arisman. (2012). Keracunan Makanan. Jakarta : Buku Kedokteran EGC.

Badan Pengawas Obat dan Makanan. (2012). Tata Cara Pemeriksaan Sarana Produksi Pangan Industri Rumah Tangga. Jakarta: BPOM.

Kemenkes RI.( 2018). Profil Kesehatan Indonesia Tahun 2017. Jakarta : Kementrian Kesehatan Indonesia.

Dinas Kesehatan Kota Jambi. (2018). Data Industri Pengrajin MakananTahun 2018. Jambi.

Fajriansyah. (2016). Hygiene dan Sanitasi Pengolahan Roti Pada Pabrik Roti Paten Bakery. Aceh Nutrition Journa, November 2016. Vol.1. No.2. 116-120. 
Erris \& Marinawati. (2014). Hubungan Pengetahuan, Motivasi, dan Peran Petugas Terhadap Kondisi Hygiene Sanitasi Makanan Jajanan Kaki Lima di Wilayah Kerja Puskesmas Aurduri Kota Jambi Tahun 2014. Scientia Journal, Mei 2015. Vol 4. No.1.

Notoatmodjo S. (2007). Promosi Kesehatan \& Ilmu Perilaku. Jakarta : Rineka Cipta

Mulyani, Roza. (2014). Pengetahuan Sikap dan Perilaku Hygiene Sanitasi Makanan. Jurnal Keperawatan, April 2014. Vol. 10. No.1.

Notoatmodjo S. (2012). Promosi Kesehatan \& Perilaku Kesehatan. Jakarta : Rineka Cipta

Bangun, Wilson.( 2012). Manajemen Sumber Daya Manusia. Jakarta : Gelora Aksara Pratama.

Harnani, Y \& Uatmi, T. (2018). Faktor-faktor yang Berhubungan dengan Higiene dan Sanitasi Rumah Makan di Kelurahan Tangkerang Labui Kota Pekanbaru. Collaborative Medical Journal. Vol 3.No.2. 11-20. 